\title{
Poljỉc:
}

Journal of the

Australasian Political Studies

Association

EDITOR

Ian McAllister

MANAGING EDITOR

David W. Lovell

REVIEW EDITOR

William Maley

'Politics' is published twice a year in May and November

\section{Subscription Rates,}

1991 (one year)

Institutional

$£ 25$ US $\$ 40$

Individual

$£ 20$ US $\$ 35$
Politics is the official journal of the Australasian Political Studies Association. Politics publishes articles on all aspects of politics. The journal aims to:

- present academic assessment of important theoretical and empirical issues in the study of politics;

- contribute to contemporary debates about controversial issues;

- present overviews and evaluations of contemporary political events, in Australasia and internationally.

Politics also publishes research notes, which report on ongoing research projects, research designs and preliminary findings. The journal has an extensive book review section, including review essays in addition to shorter reviews.

'Politics' is published by the Department of Politics, Australian Defence Force Academy, Canberra, ACT Australia 2600 


\section{LSU \ Press}

Hans J. Morgenthau and the Ethics of American Statecraft Greg Russell

In this sweeping philosophical inquiry into the pioneering work of the American political philosopher Hans J. Morgenthau, Greg Russell differentiates Morgenthau's philosophy of realism from the European heritage of Machiavellianism or raison d'état. $\$ 27.50$

\section{Antonio Gramsci}

Architect of a New Politics

\section{Dante Germino}

Dante Germino's probing biography of the Italian communist and political theorist Antonio Gramsci analyzes Gramsci's remarkable life as well as his extensive oeuvre, from the early Turin articles to the meditative Prison Notebooks.

$\$ 37.50$, cloth

$\$ 16.95$, paper

\section{Voegelin on the Idea of Race}

An Analysis of Modern European Racism

Thomas W. Heilke

In 1933, Eric Voegelin published two important books on the subject of race, Race and State and The History of the Race Idea. Thomas Heilke presents the first detailed discussion of these works as he explores Voegelin's early analysis of the forces behind the rise of racism in Europe.

$\$ 22.50$

\section{New in Paper}

\section{Realist Thought from Weber to Kissinger}

Michael Joseph Smith

"This book provides a timely addition to the reassessment of realism which is currently going on in the study of international relations."

-Journal of International Studies \$9.95, paper 


\section{The Collected Works of Eric Voegelin}

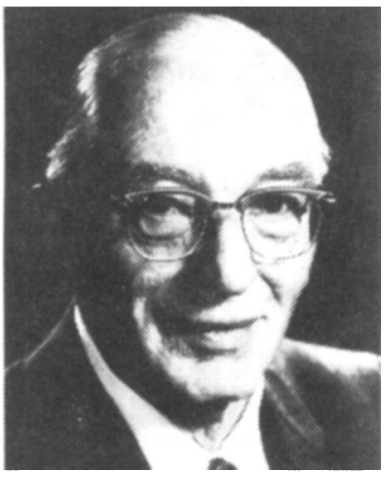

The Collected Works of Eric Voegelin will make available in a uniform edition all of Voegelin's major writings, including the monumental, never-before-published Studies in the History of Political Ideas; important published essays not previously collected in book form or published only in German; previously unpublished essays; selected correspondence; translations of seven books, four of them never before available in English; and the five-volume Order and History.

\section{Just Published}

\section{Published Essays}

1966-1985

The Collected Works of Eric Voegelin, Volume 12

Edited with an Introduction by Ellis Sandoz

Published Essays, 1966-1985 includes some of the most trenchant and compelling of Eric Voegelin's work and is an indispensable companion to his Anamnesis and to the fourth and fifth volumes of Order and History.

$\$ 32.50$
What Is History? And Other Late Unpublished Writings

The Collected Works of

Eric Voegelin, Volume 28

Edited with an Introduction by

Thomas A. Hollweck and

Paul Caringella

This volume contains the most significant pieces of unpublished writing completed by Voegelin during a period in which the conception of his main work was undergoing frequent and perhaps fundamental changes.

$\$ 22.50$

\section{Also Available}

Autobiographical Reflections

Eric Voegelin

Edited with an Introduction by Ellis Sandoz

"We are indeed fortunate that one of the twentieth century's authentic titans in philosophy and history thought to set down his autobiographical reflections before his passing. It is hard to imagine a more lustrous and also engrossing memoir." $\$ 16.95$

-Robert Nisbet

Louisiana State University Press

Baton Rouge 70893 


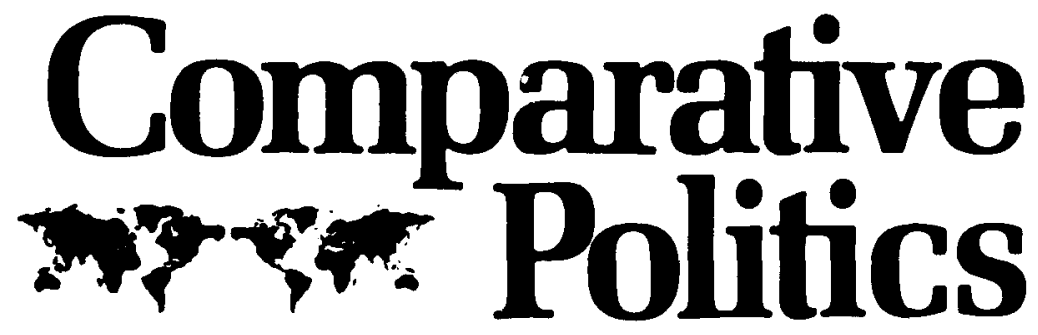

Editor-in-Chief: Dankwart A. Rustow

(City University of New York)

Comparative Politics is an international journal containing articles devoted to comparative analysis of political institutions and behavior. Articles range from political patterns of emerging nations to contrasts in the structure of established societies. Comparative Politics communicates new ideas and research findings to social scientists, scholars, and students. The journal is indispensable to experts in research organizations, foundations, consulates, and embassies throughout the world.

1991 issues to include:

Hector E. Schamis, "Reconceptualizing Latin American Authoritarianism in the 1970s: From Bureaucratic-Authoritarianism to Neoconservatism" . . Theodore P. Wright, Jr., "Center-Periphery Relations and Ethnic Conflicts in Pakistan: Sindhis, Muhajirs, and Punjabis" ... Anthony W. Marx, "Race, Nation, and Class Based Ideologies of Recent Opposition in South Africa". . . Peter Swenson, "Labor and the Limits of the Welfare State: The Politics of Intraclass Conflicts and Cross-Class Alliances in Sweden and West Germany" ... James P. McGregor, "Value Structures in a Developed Socialist System: The Case of Czechoslovakia" . . Kevin J. Middlebrook, "The Politics of Industrial Restructuring: Transnational Firms' Search for Flexible Production in the Mexican Automobile Industry" ... John B. Goodman, "The Politics of Central Bank Independence"

Published quarterly.

Subscription rates: Individuals $\$ 28 / 1$ yr., $\$ 52 / 2$ yrs., $\$ 72 / 3$ yrs.; Institutions $\$ 45 / 1$ yr., $\$ 83 / 2$ yrs., $\$ 116 / 3$ yrs.; Students $\$ 12 / 1$ yr.; Outside the U.S.A. add $\$ 6 / 1$ yr., $\$ 11 / 2$ yrs., $\$ 16 / 3$ yrs.; Airmail add $\$ 16 / y r$.; Single copies $\$ 8.50 /$ individuals, $\$ 13$ institutions.

ISSN 0010-4159.

Please address inquiries and orders to:
Comparative Politics Subscription Fulfillment Office 49 Sheridan Avenue Albany, NY 12210 


\section{transaction}

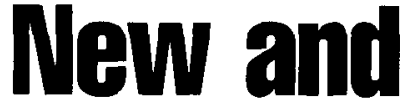

\section{Recent}

Books on
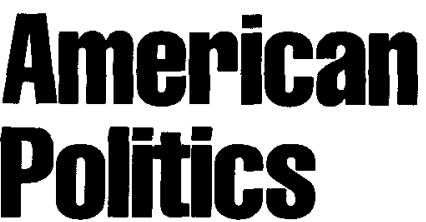

At your bookstore or direct from the publisher. Major credit cards accepted.

Call (201) 932-2280

\section{transaction publishers}

Department AMP!14

Rutgers-The State University

New Brunswick, N.J. 08903
DILEMMAS OF PRESIDENTIAL

LEADERSHIP

FROM WASHINGTON THROUGH LINCOLN

\section{Richard Ellis and Aaron Wildavsky}

This book challenges the widely accepted distinction between "traditional" and "modern" presidencies. The unique dimension of this volume is its use of cultural theory to explain presidential behavior.

ISBN: 0-88738-221-5 (cloth) $546 \mathrm{pp}$.

$\$ 39.95$

\section{VOTERS, ELECTIONS, AND PARTIES}

THE PRACTICE OF DEMOCRATIC THEORY

\section{Gerald M. Pomper}

For over two decades the author has explored the empirical realities of mass politics and their implications for democracy, particularly in the United States. Combining empirical methodology with value-informed theory, he asserts the viability of contemporary democracy.

ISBN: 0-88738-160-X (cloth) $320 \mathrm{pp}$

$\$ 29.95$

\section{CHANGING COURSE}

CIVIL RIGHTS AT THE CROSSROADS

\section{Clint Bolick}

This book identifies clearly real civil rights problems of today as government-erected barriers to entrepreneurial and educational opportunity as well as a vicious cycle of dependency and despair.

"...a fine, well-balanced contribution to the real struggle for civil rights in America..."

Walter M. Williams, George Mason University

ISBN: 0-88738-179-0 (cloth) 192 pp. $\quad \$ 28.95$

\section{CAPTIAL CORRUPTION}

THE NEW ATTACK ON AMERICAN DEMOCRACY

\section{Amital Etzioni}

The appearance in paperback of this slashing critique is mertited not simply by the quality of its analysis, but by the problems it poses. As the author notes in his new introduction, political corruption, as measured by campaign contributions of special interests to elected officials, increased significantly from 1980 to 1986 .

ISBN: 0-88738-708-X (paper) 357pp. $\quad \$ 16.95$ 


\section{PARLIAMENTARY}

\section{AFFAIRS}

\section{A Journal of Comparative Studies}

This established academic quarterly covers all aspects of government and politics directly or indirectly connected with Parliament and parliamentary systems

in Britain and throughout the world. It combines research articles with topical papers that interest a wide range of teachers and students.

Recent articles include

R.K. Alderman and Martin J. Smith

Can Prime Ministers be Pushed Out?

Susan McRae

Women at the Top in British Politics

Austin Mitchell

Beyond Televising Parliament: Taking Politics to the People

Philip Norton

Choosing a Leader: Margaret Thatcher and the

Parliamentary Conservative Party 1989-1990

Joan Isaac

The New Right and the Moral Society

Stephen White and Gordon Wightman

Gorbachev's Reforms: The Soviet Elections of 1989

David Childs

East Germany's First Free Election

Colin Knox

Sinn Fein and Local Elections

Subscription Rates Volume 44, 1991 (4 issues)

UK \& Europe $\$ 44.00$, elsewhere US $\$ 85.00$

To subscribe, obtain further information or a free sample copy of Parliamentary Affalrs please write to: Journals Marketing (EX), Oxford University Press, Southfield Road, Eynsham, Oxford OX8 1JJ, UK

Published in association with

The Hansard Society

for Parliamentary Government

OXFORD UNIVERSITY PRESS 
Lewis J. Edinger

Approaches to the Comparative Analysis of Political Leadership

Fred Dallmayr

Rethinking the Political: Some Heideggerian Contributions

Jerry Weinberger

The Politics of Bacon's History of

Henry the Seventh

John Brigham

Bad Attitudes: The Consequences of Survey Research for Constitutional Practice

Daniel H. Levine

Review Essay: Considering Liberation Theology as Utopia 